National Marine

Fisheries Service

NOAA
Fishery Bulletin

कo established in 1881 \%
Spencer F. Baird

First U.S. Commissioner of Fisheries and founder of Fishery Bulletin

\begin{abstract}
The longfin mako (Isurus paucus) is a poorly studied oceanic shark taken in fisheries throughout its worldwide range in temperate and tropical waters. Satellite-linked tags were deployed to investigate the movements of 2 mature males, one tagged in the northeastern Gulf of Mexico (GOM) and the other off northern Cuba. Horizontal tracks estimated by using likelihood methods were similar for these sharks; comparable movements were documented from the GOM, through the Straits of Florida and the $\mathrm{Ba}$ hamas, and into the open Atlantic Ocean where they converged on the Mid-Atlantic Bight. Depth and temperature ranges were $0-1767 \mathrm{~m}$ and $4.0-28.8^{\circ} \mathrm{C}$. A diel pattern of vertical movement was evident for both individuals, along with regular forays from cold daytime depths to warmer near-surface waters, possibly as an adaptation for thermoregulation. The vertical movements of longfin makos allow them to exploit vertically migrating prey but these movements increase their vulnerability to

\author{
Robert E. Hueter (contact author)' \\ John P. Tyminski ${ }^{1}$ \\ John J. Morris ${ }^{1}$ \\ Alexei Ruiz Abierno² \\ Jorge Angulo Valdes ${ }^{2,3}$ \\ Email address for contact author: rhueter@mote.org \\ ${ }^{1}$ Center for Shark Research \\ Mote Marine Laboratory \\ 1600 Ken Thompson Parkway \\ Sarasota, Florida 34236 \\ 2 Centro de Investigaciones Marinas \\ Universidad de la Habana \\ Calle 16, No. 114 e/ 1 ra y 3 ra \\ Miramar, Playa, La Habana CP 11300, Cuba \\ ${ }^{3}$ School of Natural Resources and Environment \\ University of Florida \\ P.O. Box 116455 \\ Gainesville, Florida 32611
} pelagic longlining. The horizontal movements of these sharks reveal the limited benefit of areas currently closed to pelagic longlining off the southeastern United States and also indicate the connectivity of U.S., Cuban, Mexican, and Bahamian waters for this species. Because of the vulnerability of longfin makos to overexploitation, improved biological information is needed for accurate stock assessments and appropriate management and conservation measures.

Manuscript submitted 15 April 2016. Manuscript accepted 29 November 2016. Fish. Bull.: 115:101-116 (2017).

Online publication date: 20 December 2016. doi: 10.7755/FB.115.1.9

The views and opinions expressed or implied in this article are those of the author (or authors) and do not necessarily reflect the position of the National Marine Fisheries Service, NOAA.
The shark genus Isurus comprises 2 species with similar morphological features, the shortfin mako ( $I$. oxyrinchus) and the longfin mako (I. paucus) (Compagno, 2001). The longfin mako is a global oceanic species that inhabits both tropical and subtropical waters (Compagno, 2001) but also ranges into temperate seas (Queiroz et al., 2006; Bustamante et al., 2009; Mucientes et al., 2013). In the western Atlantic Ocean, the longfin mako has been documented in the Gulf Stream off the eastern United States, off Cuba's northern coast, as far south as southern Brazil (Compagno, 2001), and as far north as Georges Bank (Kohler et al., 1998). In the Gulf of Mexico (GOM), longfin makos have been observed infrequently but have been reported in the northern GOM off the Mississippi River and south of Panama City, Florida (Killam and Parsons, 1986) and in the southern GOM off Tabasco, Mexico (Wakida-Kusunoki

\title{
Horizontal and vertical movements of longfin makos (Isurus paucus) tracked with satellite- linked tags in the northwestern Atlantic Ocean
}

and de Anda-Fuente, 2012). Despite its large size (to at least $417 \mathrm{~cm}$ in total length [TL]; Gilmore, 1983), the longfin mako is an understudied species, partly because of its relative rarity, its pelagic nature, and observers' confusion with its congener, the shortfin mako (Castro, 2011).

The longfin mako is not directly targeted in any fishery, but is taken as bycatch throughout its range in tropical and temperate waters by pelagic longline fisheries that target swordfish (Xiphias gladius), tuna species (Thunnus spp.), and other shark species (Reardon et al., 2006; Mucientes et al., 2013; Frédou et al., 2015). In a study of shark bycatch in the small-scale, pelagic longline fishery of northwest Cuba, Guitart Manday (1975) reported that the longfin mako was the sixth most common shark by weight of the 11 shark species reported; a more recent study of this fishery ranked the longfin mako higher in landings (Aguilar et al., 
2014). Fins of longfin makos are of desirable quality and have been reported in the Hong Kong (Clarke et al., 2006), Chilean (Sebastian et al., 2008), and Indonesian fin trades (Sembiring et al., 2015). Consequently, in some fisheries but not in the Cuban fishery, this species may be finned and discarded at sea; hence, landings of longfin makos may be underreported (Reardon et al., 2006). Given the apparent declines in some populations of the shortfin mako (Baum et al., 2003; Dulvy et al., 2008), it is likely that populations of the longfin mako have been affected by intensive pelagic longline fisheries (Reardon et al., 2006). Because of its rarity, low reproductive potential, and bycatch-induced mortality, the longfin mako is listed as vulnerable in the IUCN Red List of Threatened Species (Reardon et al., 2006) and in 2008 was added to Appendix II of the Convention on the Conservation of Migratory Species of Wild Animals (Kyne et al., 2012). In U.S. waters, retention of longfin makos has been prohibited for both commercial and recreational fishermen since 2000 under the National Marine Fisheries Service (NMFS) fishery management plan for sharks that inhabit the Atlantic Ocean and adjacent waters (NMFS $\left.{ }^{1}\right)$. In an ecological risk assessment of shark species caught in Atlantic pelagic longline fisheries, Cortés et al. (2015) ranked the vulnerability of the longfin mako among species at highest risk and highlighted the need for better basic biological information for this shark.

Satellite-linked tagging technologies have provided researchers with effective tools for revealing home ranges, movement and migration routes, and habitatuse patterns of marine predators (Hammerschlag et al., 2011). Most lamnid species have been studied by using satellite tracking. These species include the shortfin mako (Loefer et al., 2005; Stevens et al., 2010; Rogers et al., 2015), white shark (Carcharodon carcharias) (Bruce et al., 2006; Weng et al., 2007; Nasby-Lucas et al., 2009), porbeagle (Lamna nasus) (Pade et al., 2009; Saunders et al., 2011; Francis et al., 2015), and salmon shark (L. ditropis) (Weng et al., 2005, 2008). However, there are no detailed reports of satellite-tracked longfin makos from any part of the global range of this species. Conventional tagging results in U.S. waters, although sparse, indicate movement of longfin makos from the eastern GOM into the western North Atlantic Ocean, likely through the Straits of Florida (Kohler et al., 1998). We are the first to use satellite tracking as a means of assessing the behavior, ecology, and vulnerability to fisheries of this species.

\section{Materials and methods}

Two specimens of the longfin mako, one from the northeastern GOM and one from the southeastern

\footnotetext{
${ }^{1}$ NMFS (National Marine Fisheries Service). 1999. Final fishery management plan for Atlantic tuna, swordfish, and sharks, 97 p. Natl. Mar. Fish. Serv., Silver Spring, MD. [Available from website.]
}

GOM, were captured and tagged with pop-up satellite archival tags to track their horizontal and vertical movements. In 2012, a male longfin mako (LFM1) was captured during an overnight pelagic longline set deployed on 27 April in the northeastern GOM $\left(28.40^{\circ} \mathrm{N}\right.$, $85.84^{\circ} \mathrm{W}$ ) from the RV Weatherbird II of the Florida Institute of Oceanography. In 2015, a second male longfin mako (LFM2) was captured during an overnight pelagic longline set deployed from an artisanal Cuban fishing vessel on 13 February off Cojimar in northwest Cuba $\left(23.26^{\circ} \mathrm{N}, 81.98^{\circ} \mathrm{W}\right)$.

When LFM1 was captured in 2012, the sea-surface temperature (SST) was $25.3^{\circ} \mathrm{C}$ and depth to the bottom was approximately $334 \mathrm{~m}$. The gear targeted pelagic fish species and consisted of $26 \mathrm{~km}$ of mainline with $30-\mathrm{m}$ gangions composed of $136 \mathrm{-kg}$ monofilament connected through a $9 / 0$ nickel-plated swivel to $1 \mathrm{~m}$ of 0.8-mm stainless steel cable. The 202 hooks deployed were 18/0 circle hooks with zero offset and were baited with Spanish mackerel (Scomberomorus maculatus) or little tunny (Euthynnus alletteratus) and were suspended at depths $30-60 \mathrm{~m}$ below the surface. Chemical glow sticks (Chemilures, ${ }^{2}$ World Plastics, San Carlos, CA) were attached to the gangions approximately 2 $m$ above each baited hook as a fish attractant. Upon haulback of the gear the following morning on 28 April, one longfin mako was among the catch. The captured shark was lifted out of the water and brought on deck with a specially designed cradle to support the shark's body weight (Grace et al., 2007). The animal remained within this cradle for measuring and tagging procedures, during which time its gills were irrigated with seawater from a hose inserted into its mouth.

The shark was tagged with a pop-up satellite archival tag (Mk10; Wildlife Computers, Redmond, WA). The tag archived measurements of ambient temperature, pressure, and light level at 3 -s intervals and summarized these data into 8 -h periods to facilitate data transmission. The tag was programmed to detach after $90 \mathrm{~d}$ on the shark, float to the sea surface, and transmit a summary of its archived data by way of the Argos satellite system with time-at-depth and time-attemperature histograms in 14 user-defined bins. Black antifouling paint (EP-2000; ePaint Company, East Falmouth, MA) before deployment had been applied to the tag, excluding its sensors and label. At deployment, the tag was inserted into the shark's dorsal musculature just below the first dorsal fin by using a stainless steel dart (Type SSD; $34.0 \times 8.5$ mm; Hallprint Pty. Ltd., Hindmarsh Valley, Australia) attached to a $15-\mathrm{cm}$ tether composed of 55-kg coated, braided wire (Berkley, Spirit Lake, IA). To avoid tag destruction from extreme depth, a mechanical release device (RD1800; Wildlife Computers), designed to release at a depth of $1800 \mathrm{~m}$, was threaded inline at the midpoint of the tether. The tether, excluding the portion with the RD1800 device,

\footnotetext{
${ }^{2}$ Mention of trade names or commercial companies is for identification purposes only and does not imply endorsement by the National Marine Fisheries Service, NOAA.
} 
was protected with heat shrink tubing (3M, Two Harbors, MN). A conventional Rototag (Dalton ID Systems Ltd, Henley-on-Thames, UK) and dart tag (Hallprint Pty. Ltd.) also were applied to the shark's first dorsal fin and dorsal musculature, respectively. The condition of the tagged shark at release was scored as condition 4 (>30 s of revival time, limited swimming on release) according to the release condition categories of Hueter et al. (2006).

In 2015, when LFM2 was captured, the SST was $25.7^{\circ} \mathrm{C}$ and depth to the bottom was approximately 750 $\mathrm{m}$. The gear targeted pelagic fish species, in particular istiophorids and swordfish, and consisted of $8 \mathrm{~km}$ of mainline with gangions of 20-30 m, both composed of 2 -mm twisted monofilament. The 66 hooks deployed were either $15 / 0$ or $16 / 0 \mathrm{~J}$ hooks baited with salted clupeid and cyprinid fish species (e.g., silver carp [Hypophthalmichthys molitrix]), and suspended approximately $40 \mathrm{~m}$ below the surface. The fishermen attached battery-powered light-emitting devices (known locally in Cuba as lampos) to the gangions approximately $3 \mathrm{~m}$ above each baited hook. During gear retrieval in the early morning of 14 February, the hooked shark was transferred from the fishing vessel to a research boat, secured by tail rope at the stern, and maintained in the water during the process of taking measurements and tagging.

This shark (LFM2) was tagged with a MiniPAT (Wildlife Computers) that archived measurements of temperature, pressure, and light level at 5-s intervals and summarized these data into 6 -h periods. The tag was programmed to detach from the shark after 150 $\mathrm{d}$, and the time-at-depth and time-at-temperature histograms of the data were distributed among 12 userdefined bins. Unlike the Mk10 tag, which was deployed on LFM1, the MiniPAT sends time-series data of depth and temperature by way of the Argos satellite system in addition to archiving that data. A clear antifouling coating (Propspeed, Propspeed USA, Miami, FL) had been applied to the tag, excluding its sensors and release pin. At deployment, the tag was inserted into the dorsal musculature of the shark just below the first dorsal fin by using a plastic anchor (Domeier; $20 \times 14$ $\mathrm{mm}$; Wildlife Computers) attached to a $15-\mathrm{cm}$ tether composed of stainless steel wire rope with a $23-\mathrm{kg}$ load capacity (type 18-8; McMaster-Carr, Santa Fe Springs, CA). A newer version of the RD1800 device was employed with an internal pin that breaks under pressure at a depth of $1800 \mathrm{~m}$, releasing the tag from the tether. The tether, excluding the portion of the RD1800 device, was protected with heat shrink tubing (3M). No conventional tag was applied to this shark. The condition of the shark at release was classified as condition 2 (no revival time required, slow but strong swimming on release; Hueter et al., 2006).

For both sharks, species identification was determined by the presence of taxonomic characteristics of the genus Isurus (Campagno, 2001), together with a first dorsal fin well behind the free rear tip of the pectoral fin, dark coloration on the ventral surface of the snout, and long pectoral fins, all of which collectively distinguish the longfin mako from the shortfin mako (Guitart Manday, 1966; Garrick, 1967; Bustamante et al., 2009). Maturity of the 2 males was assessed by stage of clasper development and its condition.

Compiled data collected through the Argos system were uploaded to the Wildlife Computers Data Portal (website) for processing with GPE3 software (Wildlife Computers). This statistical processing tool runs exclusively on the tag manufacturer's Internet servers. The GPE3 software uses tag data and corresponding SST (NOAA Optimum Interpolation (OI) SST V2 High Resolution) and bathymetry (NOAA ETOP01 global relief model, Bedrock version) reference data as inputs into its gridded hidden Markov model to generate the most likely animal location for a given time, as well as a distribution of likelihoods as an indicator of location quality. This model provides an overall score as an indicator of how well the model fits the observed data. We ran the model with varying inputs for the parameter of animal speed to generate a fit with an optimal score and realistic maximum likelihood track (MLT). Optimal MLTs for LFM1 and LFM2 were generated by using animal speed inputs of 4.5 and $2.5 \mathrm{~m} / \mathrm{s}$, respectively. The total distance of the MLT was calculated with GE-Path software (vers. 1.4.5). Likelihood surfaces were generated by using the raster and ncdf packages for statistical software $R$, vers. 3.2.3 (R Core Team, 2015) and by using the script made available by the tag manufacturer. For comparing the MLT with SST, we produced imagery in $\mathrm{R}$ from the Group for High Resolution Sea Surface Temperature (GHRSST) global 1-km SST data set (website) using functions in the fields, maps and raster packages for $R$.

We assigned a diel period to each record (day, night, dawn, dusk) in the time-series data sent by the MiniPAT. To approximate the times of sunrise and sunset for a given date and location (from the MLT), we consulted an online calculator (website). On the basis of these estimates, dawn was defined as the 30-min period before and after sunrise, and dusk was defined as the 30 -min period before and after sunset. To evaluate differences in percent time at depth and percent time at temperature between the 2 sharks and to test differences between day and night, we performed 2-sample Kolmogorov-Smirnov (K-S) tests. Mean depths between diel periods were compared with Welch's unequal variances $t$-test. These statistical analyses were performed by using the stats package for $R$ ( $R$ Core Team, 2015).

To further investigate the environmental drivers of behavior, we used the time-series depth data from the MiniPAT to calculate vertical speed (as a proxy for activity level) for comparison with the corresponding temperature at depth. The difference between sequential depth data points was used to determine vertical velocity. The absolute value of the vertical velocity was considered the vertical speed. We then examined the relationship between daily mean vertical speed and minimum (daytime) and maximum (nighttime) temperatures during that segment of the day, using a linear 


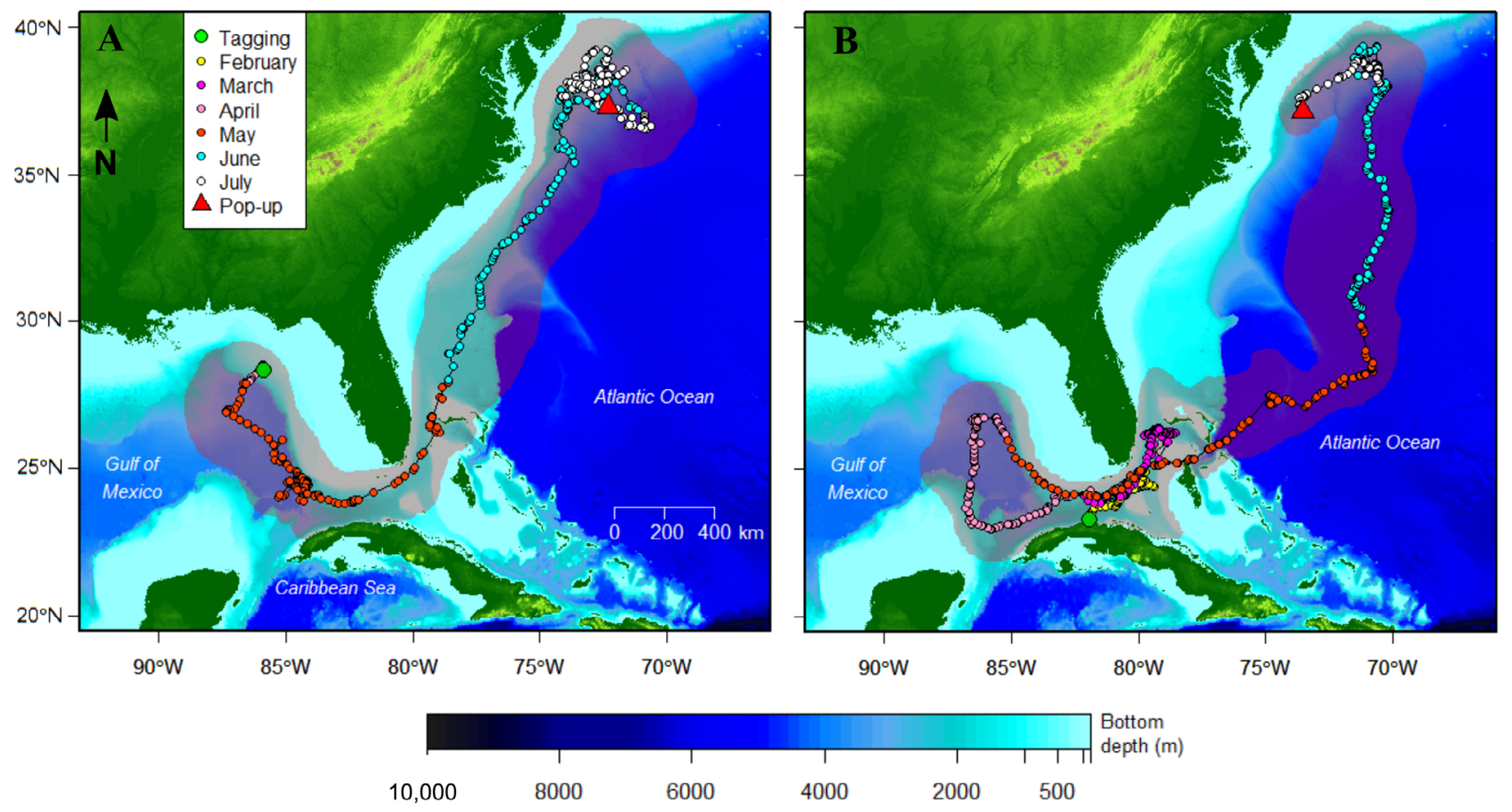

Figure 1

The model-derived maximum likelihood tracks for 2 longfin makos (Isurus paucus) and the locations where they were tagged and where their pop-up tags were released: (A) the first longfin mako, LFM1, was tagged 28 April 2012 off northwest Florida, and (B) the second longfin mako, LFM2, was tagged 14 February 2015 off Cojimar, Cuba. Shaded areas around the tracks represent $99 \%$ likelihood surfaces of track locations. The bathymetric scale represents water depth (in meters) to the bottom.

least-squares regression analysis. This analysis was also used to examine the relationship between daytime interforay duration and mean temperature, as well as to test for a possible correlation between mean nighttime depth and moon phase. For the latter analysis, moon illumination data were acquired from the U.S. Naval Meteorology and Oceanography Command (website) and were arcsine-transformed before statistical analysis (Abascal et al., 2010). All regression analyses were performed in SigmaPlot 10.0 (Systat Software Inc., San Jose, CA).

\section{Results}

On 28 April 2012, LFM1, a mature male (precaudal length $[\mathrm{PCL}]=201 \mathrm{~cm}$ ), was tagged with a Mk10 popup satellite archival tag in the northeastern GOM. The 90-d tag was released on schedule and began transmitting on 27 July 2012. The first location recorded through the Argos system $\left(37.46^{\circ} \mathrm{N}, 72.35^{\circ} \mathrm{W}\right)$ was 330 $\mathrm{km}$ east-northeast of Virginia Beach, Virginia, a minimum at-sea distance of $2233 \mathrm{~km}$ from the tagging site (Fig. 1A). Transmitted data were received over a period of $8 \mathrm{~d}$, providing approximately $70 \%$ of the summary data. Therefore, although the condition of this shark was judged to be relatively poor (condition 4) when tagged and released, the transmitted data revealed that this animal survived the capture-and-release event.

On 14 February 2015, LFM2, a mature male measuring $190 \mathrm{~cm}$ PCL, was tagged with a MiniPAT off the northern coast of Cuba. The 150-d tag was released on schedule and began transmitting on 15 July 2015. The first location recorded through the Argos system $\left(37.21^{\circ} \mathrm{N}, 73.51^{\circ} \mathrm{W}\right)$ was $223 \mathrm{~km}$ east-northeast of Virginia Beach, Virginia, a minimum at-sea distance of $1762 \mathrm{~km}$ from the tagging site (Fig. 1B). The tag transmitted data for 21 days, providing approximately $82 \%$ of the summary data.

\section{Horizontal movements}

During the first 3 weeks after tagging, LFM1 remained off the continental shelf in the eastern GOM, moving in a southeasterly direction (Fig. 1A). By the third week of May, the shark entered the Straits of Florida and then continued on an easterly path in the waters between Cuba and the Florida Keys. Then LFM1 moved in a northeasterly direction and entered waters of the Bahamas by the end of May, passed to the west of Grand Bahama Island, and moved into the open Atlantic Ocean by early June. During the first 3 weeks of June, the shark maintained a northeasterly direction until reaching continental shelf edge waters offshore of the mouth of Chesapeake Bay. For the rest of its track, 

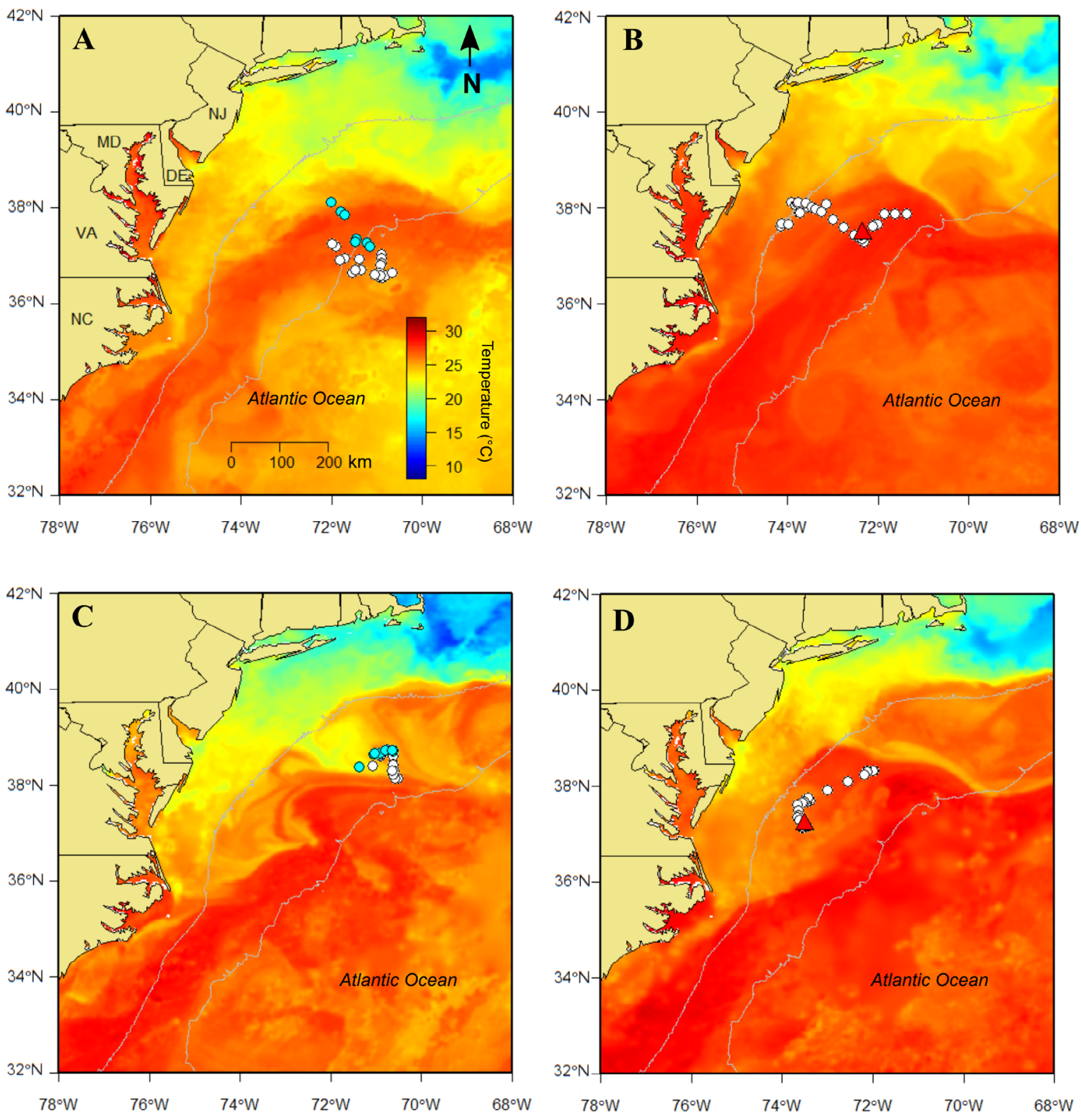

Figure 2

Locations of warm water from the Gulf Stream during late June and July and estimated positions of longfin makos (Isurus paucus) tracked with satellite-linked tags in the northwestern Atlantic Ocean. (A) Track of the first shark, LFM1, from 29 June to 5 July 2012 in relation to sea-surface temperature (SST) for 2 July 2012. (B) Track of LFM1 for the period 21-27 July 2012 in relation to SST for 24 July 2012. (C) Track of the second shark, LFM2, from 29 June to 5 July 2015 in relation to SST for 2 July 2015. (D) Track of LFM2 for the period 9-15 July 2015 in relation to SST for 12 July 2015. Blue and white circles represent positions in June and July, respectively. Red triangles mark the locations where the pop-up tag was released. The gray lines represent the 1000-m and 4000-m depth contours.

LFM1 remained within warm Gulf Stream waters and largely off the continental shelf $100-400 \mathrm{~km}$ from the coasts of Delaware, Maryland, and Virginia (Fig. 1A; Fig. 2, $\mathrm{A}$ and $\mathrm{B}$ ). The northernmost position of the track $\left(39.25^{\circ} \mathrm{N}, 72.83^{\circ} \mathrm{W}\right)$ was reached on 11 July. The total distance of the MLT was $6809 \mathrm{~km}$, representing a mean movement rate of $75.7 \mathrm{~km} / \mathrm{d}$.
The MLT for LFM2 displayed movement from the northern coast of Cuba into the Straits of Florida in the latter half of February, followed by movements into waters of the Bahamas by early March (Fig. 1B). Then LFM2 remained in Gulf Stream waters between Grand Bahama Island and southeast Florida for a period of about 3 weeks. By late March and early April, 
the shark moved back through the Straits of Florida in a westerly direction. After reaching the edge of the Yucatan shelf by mid-April, LFM2 moved northward into the GOM. By the beginning of May, the shark initiated southerly movements and re-entered the Straits of Florida, and it was located south of the Florida Keys by the first week of May. Next, LFM2 continued on an easterly to northeasterly path through the Bahamas (north of Andros Island), into the open Atlantic Ocean, and off the continental shelf. This shark continued in a northeasterly direction during the latter half of May. Then LFM2 remained in pelagic waters and shifted to a northerly direction during the month of June. On 24 June, the shark reached its northernmost position $\left(39.38^{\circ} \mathrm{N}, 70.65^{\circ} \mathrm{W}\right)$ before moving in a southwesterly direction during July to the point where its tag was detached (on 15 July). During late June and the first half of July, LFM2 remained within the Gulf Stream and off the continental shelf, approximately $140-330 \mathrm{~km}$ from the coasts of New Jersey, Delaware, Maryland, and Virginia (Fig. 2, C and D). The total MLT covered $8826 \mathrm{~km}$, a mean movement rate of $58.8 \mathrm{~km} /$ day.

By comparing the 2 tracks for the calendar days they had in common, one in 2012 and the other in 2015, one can observe a high degree of synchronicity in the movements of these sharks in the GOM and Straits of Florida, in their parallel tracks northward in the Atlantic Ocean, and in their convergence in the Mid-Atlantic Bight (MAB) (Fig. 3). In U.S. territorial waters, a broad system of areas in the GOM and off the Atlantic coast are closed year-round or seasonally to pelagic longline fishing $\left(\mathrm{NMFS}^{3}\right)$. Both LFM1 and LFM2 stayed largely outside these protected areas (Fig. 3).

\section{Vertical movements}

Both sharks undertook daily vertical movements and portions of most days were spent near the surface and at depths in excess of $200 \mathrm{~m}$. For LFM1, the depth and temperature ranges experienced during its recorded track were $6-952 \mathrm{~m}$ and $4.6-28.8^{\circ} \mathrm{C}$. The mean daily vertical range (i.e., difference between minimum and maximum depths) was $494.7 \mathrm{~m}$ (standard deviation [SD] 173.8). For LFM2, the ranges in depth and temperature were $0-1767 \mathrm{~m}$ and $4.0-28.4^{\circ} \mathrm{C}$. The mean

\footnotetext{
${ }^{3}$ NMFS (National Marine Fisheries Service). 2016. Pelagic longline restrictions. In HMS commercial compliance guidance: guide for complying with the Atlantic tunas, swordfish, shark, and billfish regulations, p. 17-23. Natl. Mar. Fish. Serv., Silver Spring, MD. [Available from website.]
}

daily vertical range of this shark was $435.4 \mathrm{~m}$ (SD 147.0). The depth profile for LFM2 indicates a pattern of diel vertical migration (DVM), with the shark spending nighttime toward the surface and daytime at greater depths and with periods of dawn and dusk spent largely at intermediate depths (Fig. 4). We noted evidence of seasonal variation in vertical habitat use; LFM2 remained at shallower depths at night during June and July than during other months (Fig. 4). The mean depth at daytime (321.7 $\mathrm{m}$ [SD 107.6]) was significantly deeper for LFM2 than the mean depth at nighttime (94.2 m [SD 90.2]; $P<0.0001$ ) (Fig. 5). The mean depth at dawn (245.1 m [SD 104.5]) was shallower than the mean depth at dusk (258.7 m [SD 111.9]; $P=0.023$ ) (Fig. 5).

The results from a comparison of the histogram data for the 2 sharks indicated similar time-at-depth distributions (K-S test: $P=0.575$; Fig. 6A), although some differences were noted. For example, LFM2 spent $26.1 \%$ of its time in the depth range of 300-400 $\mathrm{m}$ and LFM1 spent $10.0 \%$ of its time within that range. The first longfin mako spent more time at depths $>500 \mathrm{~m}$ (10.3\%) than did LFM2 (1.6\%; Fig. 6A). Time-at-tem- 


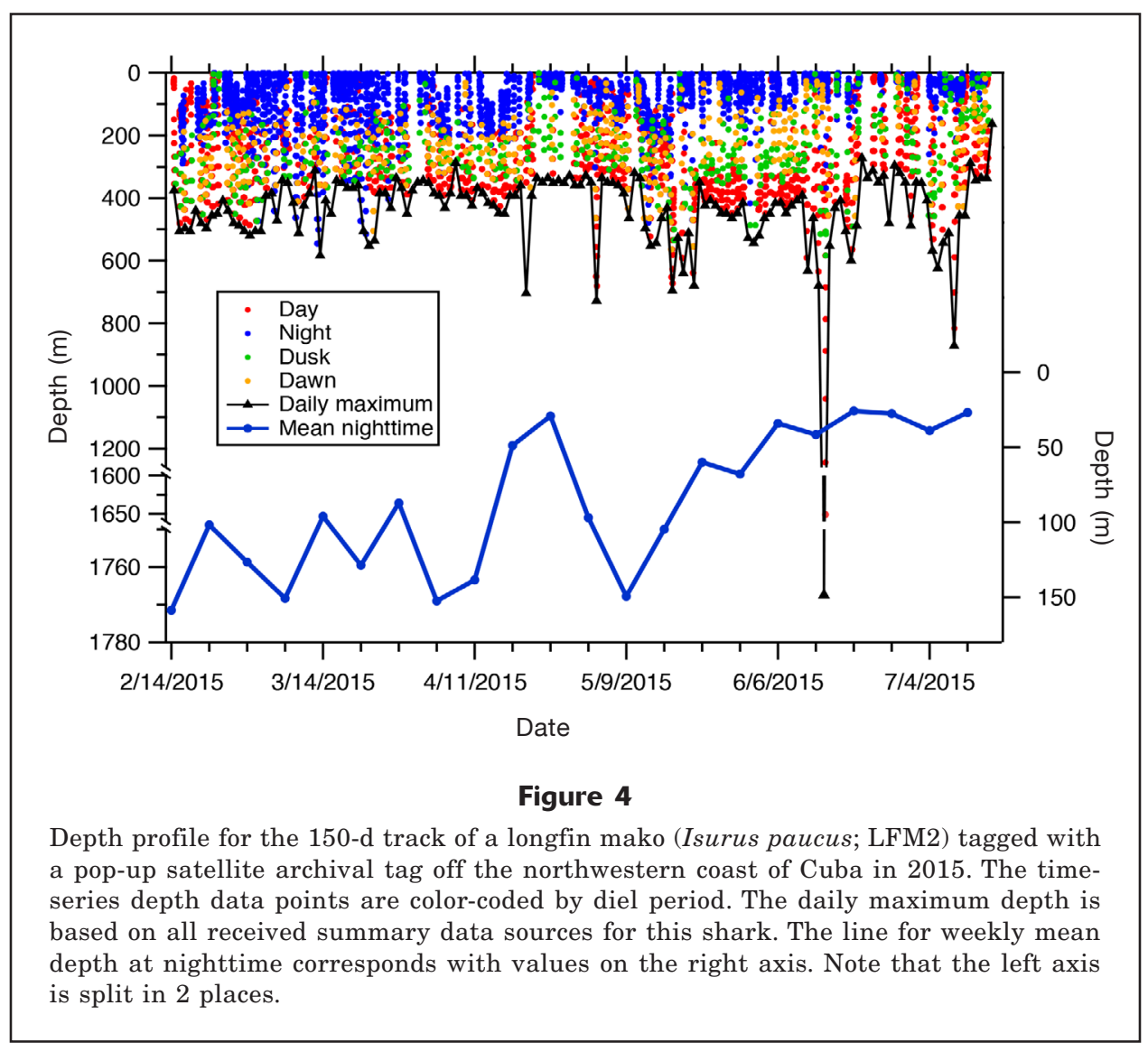

perature distributions were not significantly different for these sharks (K-S test: $P=0.989$ ), and both sharks spent the largest proportion of their time in waters with a temperature range of $24-27^{\circ} \mathrm{C}$ (Fig. 6B). Large proportions of time in cold temperatures were observed; LFM1 and LFM2 spent $19.6 \%$ and $14.5 \%$ of their time in temperatures $\leq 12^{\circ} \mathrm{C}$, respectively. We separated the binned histogram data for LFM2 into 12-h blocks of time that roughly corresponded to day (0800-2000) and night (2000-0800). The differences between day and night for time at depth (K-S test: $P=0.536$; Fig. $6 \mathrm{C}$ ) and time at temperature (K-S test: $P=0.9895$; Fig. 6D) were not significant but further highlighted the DVM pattern.

Plotting time-series depth and temperature data for LFM2 was useful for visualizing dynamic patterns in vertical movement, although the relatively low resolution of these data (10-min intervals) precluded accurate calculations of ascent and descent rates. This shark spent daytime periods largely at depth (mean daily depth: $321.7 \mathrm{~m}$ ); however, we noted upward vertical forays during these periods that appeared to be regularly timed and came closer to the surface when the temperature at depth was coldest (Fig. 7). The depth profile in Figure 7D shows that LFM2 experienced a change in temperature as high as $18.8^{\circ} \mathrm{C}$ during its upward movements but spent a relatively brief period of time in the warmer, near-surface waters (approximately 10-15 min) before initiating descent. When we examined this daytime pattern over LFM2's entire track, we found an inverse linear relationship between temperature and vertical speed (coefficient of multiple determination $\left[R^{2}\right]=0.63$; Fig. 8A).

In contrast, vertical speed during the night for this shark did not appear to be correlated with temperature $\left(R^{2}=0.001\right)$. For LFM2, mean vertical speed in the daytime $(2.3 \mathrm{~m} / \mathrm{min})$ was higher than in the nighttime (1.91 $\mathrm{m} / \mathrm{min} ; P=0.0133)$. Mean vertical speed at dawn $(3.46 \mathrm{~m} / \mathrm{min})$ did not differ from that at dusk $(3.48$ $\mathrm{m} / \mathrm{min} ; P=0.921$ ), although both crepuscular periods showed that this shark traveled at significantly higher speeds than during day and night $(P<0.0001)$. Further, we examined the durations between the upward daytime forays from depths of 250-531 $\mathrm{m}$ for the entire track of LFM2 $(n=36)$ and found that they ranged from 1.2 to $3.8 \mathrm{~h}$. The results of a linear regression indicate that the duration between these forays was correlated with the mean temperature experienced by this shark at depth $\left(R^{2}=0.60\right.$; Fig. $\left.8 \mathrm{~B}\right)$. Time-series data further revealed that LFM2 did not always remain in near-surface waters during the night because forays to depths $>250 \mathrm{~m}$ were not uncommon, particularly during the period February-May (Fig. 9). Unlike the regularly timed daytime movements from depth $(>250 \mathrm{~m})$ toward the surface, the nighttime dive profiles for this shark were more variable and indicated a period of bottom time 


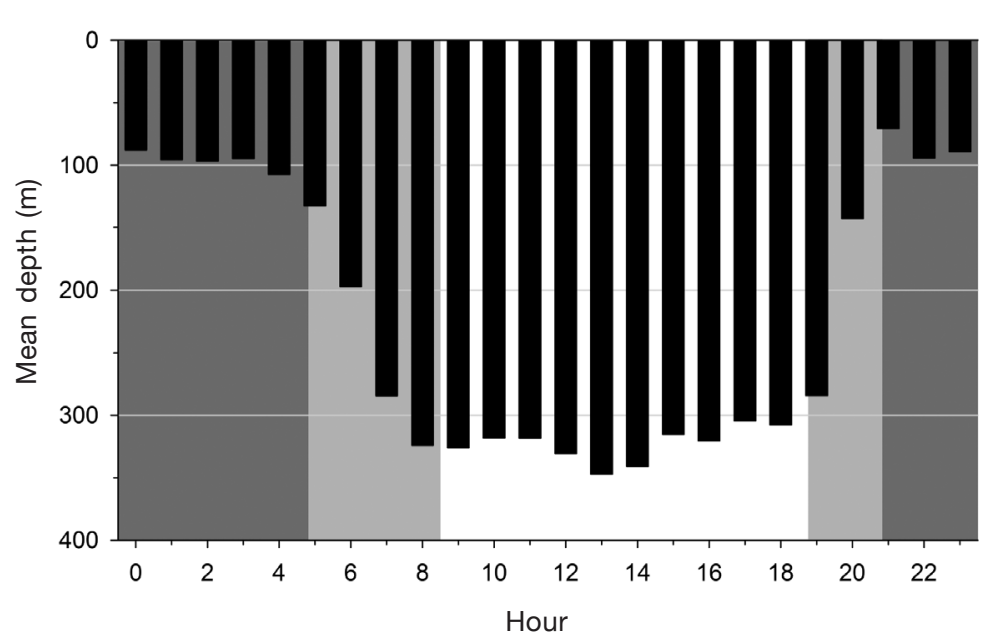

Figure 5

Mean depth by hour of the day for the 150-d track of a longfin mako (Isurus paucus; LFM2) tagged with a pop-up satellite archival tag off the northwestern coast of Cuba in 2015. Shading represents nighttime (dark gray), the variable periods of dawn and dusk that are dependent on location and date (light gray), and daytime (white). Hours are in local time (GMT-4 h; 4 hours behind Greenwich Mean Time).

rates of $74.4 \mathrm{~km} / \mathrm{d}$ (Bruce et al., 2006) and that individual white sharks travel as fast as $119 \mathrm{~km} / \mathrm{d}$ (Weng et al., 2007). Data from conventional tagging of longfin makos, although scant, have indicated movements consistent with those observed with our satellite-tracked longfin makos: 2 sharks conventionally tagged in the eastern GOM were recaptured off the coasts of northern Cuba and eastern Florida (Kohler et al., 1998). Data from a more recent return of a conventional tag from a longfin mako indicated movement from the eastern Caribbean to the continental slope off of Delaware Bay (Kohler ${ }^{4}$ ). Off the U.S. north Atlantic coast, this species has been tagged in waters along the shelf edge (at depths $>200 \mathrm{~m}$ ), and the few recaptures from this area indicate a pattern of movement eastward into deeper pelagic waters (Kohler et al., 1998).

The presence of LFM1 and LFM2 in the Straits of Florida is consistent with fisheries data from this region. In an overview of the landings of large pelagic species along the northern coast of Cuba, Guitart Manday (1975) reported that the longfin mako was captured in nearly ev-

before ascent (20-40 min). Additionally, an examination of lunar phase with mean nighttime depth did not detect any significant correlation $\left(R^{2}=0.0005\right)$.

\section{Discussion}

This article is the first published report on the movements and vertical habitat use of the longfin mako, a poorly studied shark species for which our knowledge has largely been based on incidental catches from pelagic fisheries. This study is based on 2 satellite tracks, and the results revealed similar movements of the 2 longfin makos from the GOM to the western North Atlantic Ocean, as well as a diel pattern of vertical movement, a tolerance for extended periods in deep cold water, and dynamic vertical forays.

\section{Horizontal movements and distribution}

The MLTs for the 2 longfin makos revealed long-distance movements from the eastern GOM, through the Straits of Florida, and into the open Atlantic Ocean off the northeastern coast of the United States. Although direct comparisons between movement rates are made difficult by differences in tracking or analytical methods, the rates of movement for LFM1 $(75.7 \mathrm{~km} / \mathrm{d})$ and LFM2 $(58.8 \mathrm{~km} / \mathrm{d})$ are comparable with those reported for other lamnids. Short-term acoustic tracks of shortfin makos have indicated mean speeds of $53 \mathrm{~km} / \mathrm{d}(2.2 \mathrm{~km} / \mathrm{h}$; Sepulveda et al., 2004). Migratory tracks from satellite tagging of white sharks have shown mean movement ery month but noted peaks in abundance in surveys conducted during August-November in 1971 and during April-May and August-November in 1972. Observations from recent studies of the artisanal pelagic longline fishery along the northern coast of Cuba have indicated that the longfin mako continues to be caught year-round and peaks in relative abundance during January-March (J. Angulo Valdes, unpubl. data). Dodrill and Gilmore (1979) documented a beached specimen of longfin mako at Melbourne Beach, along the east coast of Florida, during the month of December (in 1975) and made note in their addendum of 2 additional specimens captured with drift longlines at depths of 200-400 m between Jupiter and Sebastian Inlets during the months of April and May (in 1978). In a 2-year study of the shark bycatch in the swordfish fishery off the east coast of Florida, Berkeley and Campos (1988) recorded 2 longfin makos captured during the months of October and December (in 1982).

In our study, both male longfin makos moved into the MAB during the months of June and July and used outer continental shelf, slope, and oceanic habitats during this period. Conventional tagging data from this area indicated a similar distribution of captures, along with a male:female ratio of 1.9:1.0, for the longfin mako (Kohler et al., 1998). Data provided by the NMFS Pelagic Observer Program (POP) for the period 19922014 indicated that $18 \%$ of longfin makos documented

\footnotetext{
${ }^{4}$ Kohler, N. 2015. Personal commun. Northeast Fish. Sci. Cent., Natl. Mar. Fish. Serv., 28 Tarzwell Dr., Narragansett, RI 02882 .
} 


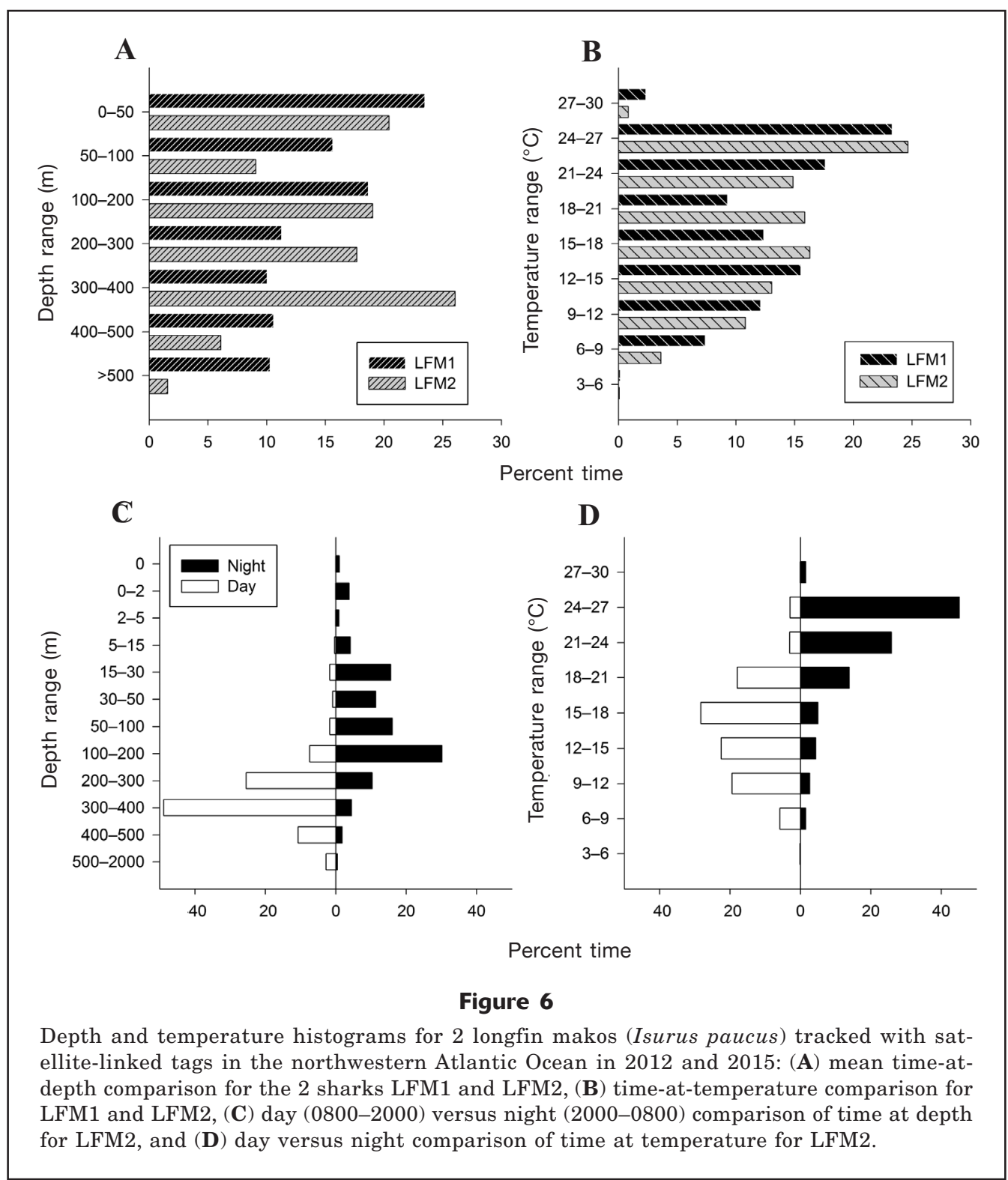

were from the MAB area (delineated as $35-43^{\circ} \mathrm{N} ; 71-$ $78^{\circ} \mathrm{W}$ ) and that the greatest proportion were landed in July and August (combined 45\%) (Cortés ${ }^{5}$ ). Of the 11 geographic areas covered by the POP, only the GOM had a larger proportion of longfin mako captures $(34 \%)$ than the MAB (Cortés ${ }^{6}$ ).

\section{Diel vertical movement}

The depth and temperature data from the tags of LFM1 and LFM2 indicate a daily pattern of vertical movement

${ }^{5}$ Cortés, E. 2015. Personal commun. Southeast Fish. Sci. Cent., Natl. Mar. Fish. Serv., 3500 Delwood Beach Rd., Panama City, FL 32408-7403.

6 Cortés, E. 2015. Personal commun. Southeast Fish. Sci. Cent., Natl. Mar. Fish. Serv., 3500 Delwood Beach Rd., Panama City, FL 32408-7403. between near-surface waters and the mesopelagic zone, with overall depth and temperature ranges of 0-1767 $\mathrm{m}$ and $4.0-28.8^{\circ} \mathrm{C}$. A pattern of DVM was evident with greater time at depth during the day and more time in the mixed layer at night. These observations are consistent with longline catches of longfin makos in that most captures occur during overnight sets with baits set at depths of 0-220 m below the surface (Dodrill and Gilmore, 1979; Queiroz et al., 2006; Hemida and Capapé, 2008; Bustamante et al., 2009). Satellite tracking results for its congener, the shortfin mako, indicate a similar DVM pattern, but shortfin makos do not appear to have as great a tolerance for depth and cold temperatures. In the western North Atlantic Ocean, for example, a tagged shortfin mako had depth and temperature ranges of $0-556 \mathrm{~m}$ and $10.4-28.6^{\circ} \mathrm{C}$ (Loefer et al., 2005), and results from tracking a shortfin mako in the 


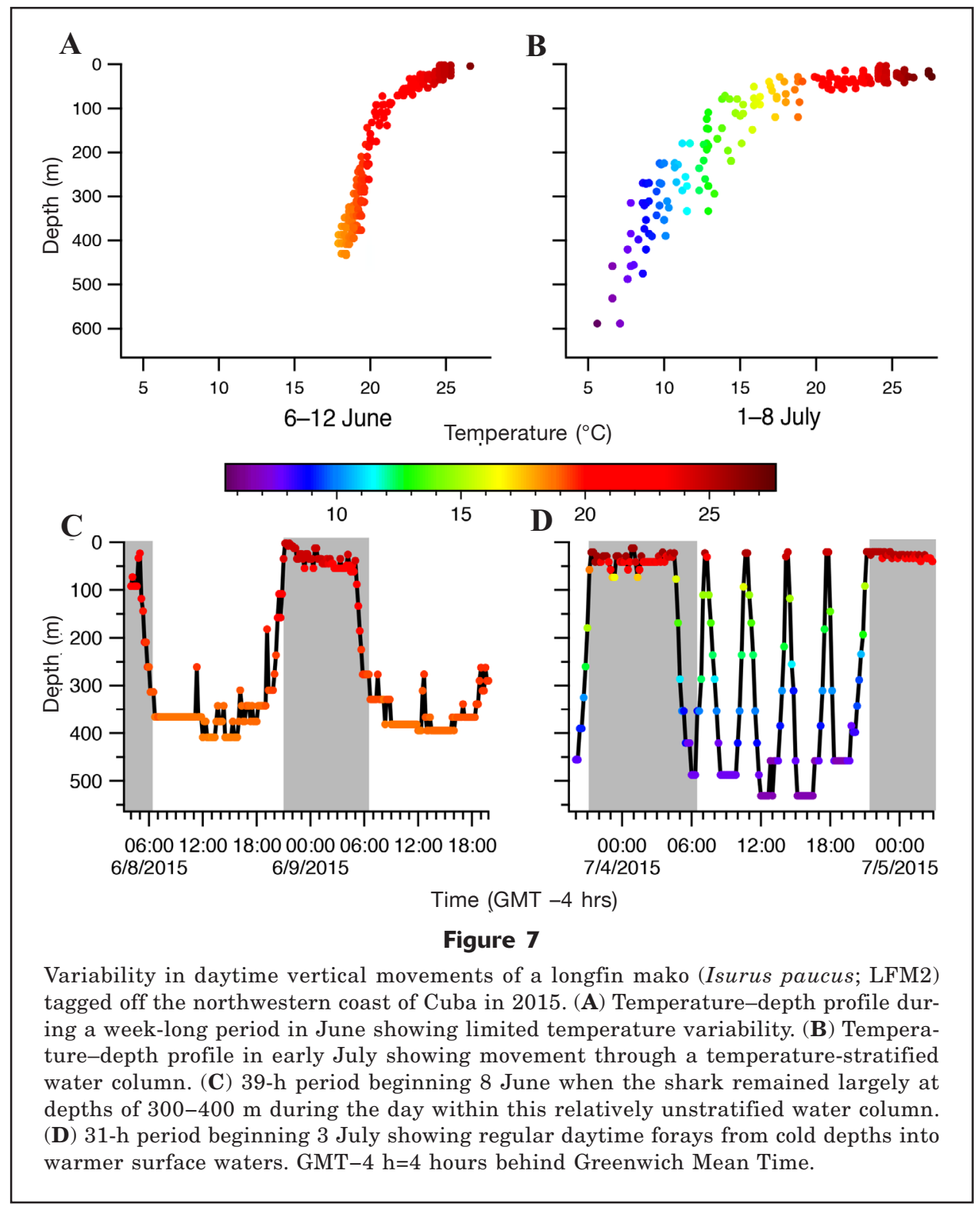

southwest Pacific indicated a comparable vertical movement pattern of shallower depths at night than those during the day, descents to $620 \mathrm{~m}$, and a temperature range of $8.8-23.4^{\circ} \mathrm{C}$ (Stevens et al., 2010).

Similar DVM behavior has been observed in a number of other pelagic shark species, including the bigeye thresher (Alopias superciliosus; Stevens et al., 2010), white shark (Nasby-Lucas et al., 2009), and porbeagle (Saunders et al., 2011), as well as in pelagic teleosts such as the swordfish (Carey and Robison, 1981; Abascal et al., 2010; Sepulveda et al., 2010) and bigeye tuna (T. obesus; Musyl et al., 2003), and it often has been suggested that this behavior is a response to the movement of their prey (Musyl et al., 2003; Stevens et al., 2010; Saunders et al., 2011). Although the diet of the longfin mako has not been described fully, the presumed prey of this species includes schooling fish and pelagic squid species (Compagno, 2001). The latter may be the more important dietary component because squid and squid beaks have been identified in the contents of stomachs of longfin makos (Dodril and Gilmore, 1979; Castro, 2011) and are similarly a known component of the shortfin mako diet (Stillwell and Kohler, 1982; Maia et al., 2006). The stomach of a 310 -cm-TL female longfin mako from the southeastern Pacific Ocean contained squid remains, most likely from jumbo squid (Dosidicus gigas; Bustamante et al., 2009). Pelagic cephalopods also have been shown to be diel vertical migrators (Roper and Young, 1975). A distinct DVM pattern was observed for jumbo squid tagged with satellite tags: they spent most daylight hours at depths $>250 \mathrm{~m}$, rose toward the surface at dusk, and spent the majority of time at night at depths $<150 \mathrm{~m}$ (Gilly et al., 2006). This pattern is similar to 


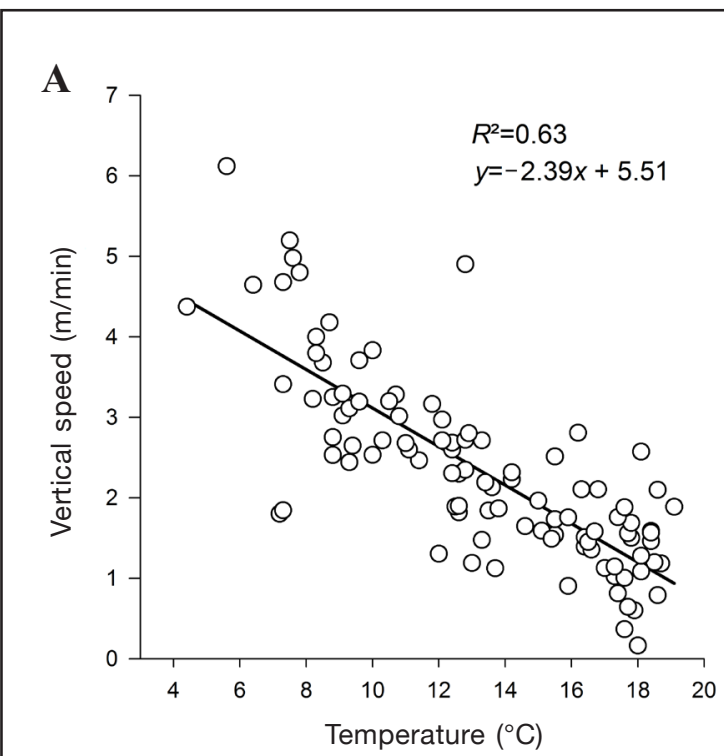

B

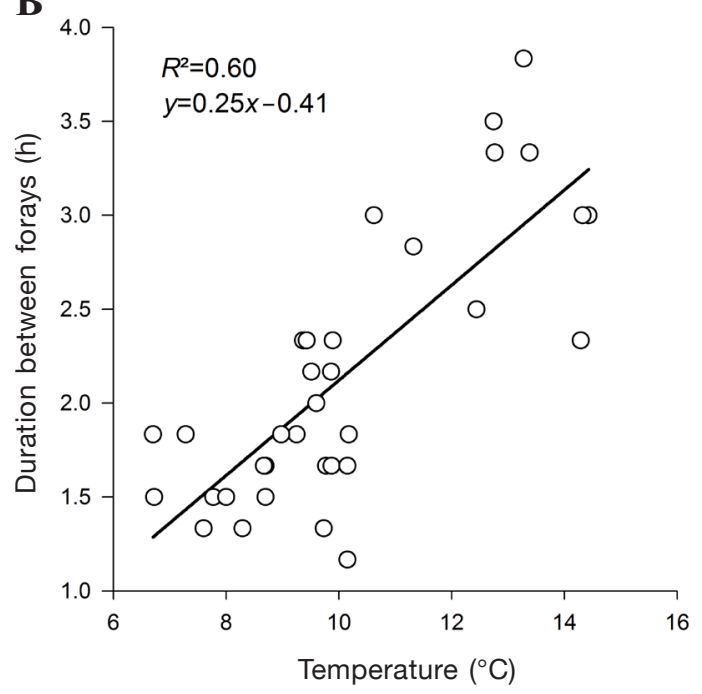

Figure 8

Relationship of daytime vertical movements and water temperature at depth for a longfin mako (Isurus paucus; LFM2) tracked with a satellitelinked tag in the northwestern Atlantic Ocean in 2015. (A) Mean daytime vertical speed and minimum temperature. (B) Daytime interforay duration and mean temperature. $R^{2}=$ the coefficient of multiple determination.

the pattern of movements of longfin makos observed in our study and indicate that the diel pattern of the longfin mako may be related to a habit of following cephalopod prey.

The importance of the convergence of the tracks of LFM1 and LFM2 in the MAB in summer is unclear, but their movements likely are influenced directly or indirectly by water temperature, given their observed tendency to remain near or within the Gulf Stream (Fig. 2 ). The water column in this region becomes strongly stratified by mid-summer and is characterized by the formation of a warm, mixed surface layer of about 30 $\mathrm{m}$ in depth (Castelao et al., 2008). We noted a shallower mean depth at nighttime $(\sim 30 \mathrm{~m})$ for LFM2 during June and July that indicates a nighttime preference for this mixed layer. Similarly, satellite tagging of bluefin tunas (T. thynnus) in the Atlantic Ocean has indicated a shallower summertime depth distribution when bluefin tunas occupy well-stratified water in this region (Galuardi and Lutcavage, 2012). The 60-d track of a shortfin mako tagged in Gulf Stream waters off South Carolina also had a decrease in nightly depth range after the summer solstice, indicating that the shark or its prey was tracking a thermal regime at night (Loefer et al., 2005). In a study of the diet of large, pelagic, predatory fish species in this same region of the North Atlantic Ocean, the most common component of stomach contents was cephalopods, and the highest biomass was represented by ommastrephid squid species (Logan et al., 2013).

Taken together, the data from these studies indicate that longfin makos use this area off the MAB as a summer feeding area and adjust their vertical movement patterns in response to seasonal changes in distributions of cephalopod or teleost prey to maximize foraging efficiency. Because both LFM1 and LFM2 were sexually mature males, we cannot discount the possibility that this area may also be a mating ground for this species. Using NMFS POP data from the MAB (Keene ${ }^{7}$ ), we estimated that $58 \%$ of female and $46 \%$ of male longfin makos caught in this area are of a sexually mature size. There is evidence that other lamnids, such as the white shark, use the MAB as both feeding and mating grounds (Gilmore, 1993). However, additional information, such as the presence of female longfin makos with fresh mating scars, will be needed to verify that the $\mathrm{MAB}$ is a mating ground for this species.

\section{Use of deep, cold habitat and endothermy}

Profiles of time at depth and time at temperature for the 2 longfin makos (Fig. 6) indicated that this species is capable of using cold, deepwater habitat for extended periods of time (42-54\% of time at depths $>200 \mathrm{~m}$; 14$20 \%$ of time at temperatures $\leq 12^{\circ} \mathrm{C}$ ), particularly during daytime hours. This pattern contrasts with that of its congener, the shortfin mako, which appears to make only brief excursions below the thermocline (Abascal et al., 2011) and reportedly spends only $4 \%$ of its time at depths greater than $300 \mathrm{~m}$ in the southwest Pacific (Stevens et al., 2010) and only about $6-10 \%$ of its time at depths exceeding $200 \mathrm{~m}$ in the northwestern Atlantic Ocean $\left(\right.$ Vaudo $\left.^{8}\right)$.

\footnotetext{
${ }^{7}$ Keene, K., Jr. 2016. Personal commun. Southeast Fish. Sci. Cent., Natl. Mar. Fish. Serv., 75 Virginia Beach Dr., Bldg. 2, Miami, FL 33149-1003.

${ }^{8}$ Vaudo, J. 2013. Personal commun. The Guy Harvey Res. Inst., Nova Southeastern Univ., 8000 N Ocean Dr., Dania Beach, FL 33004.
} 


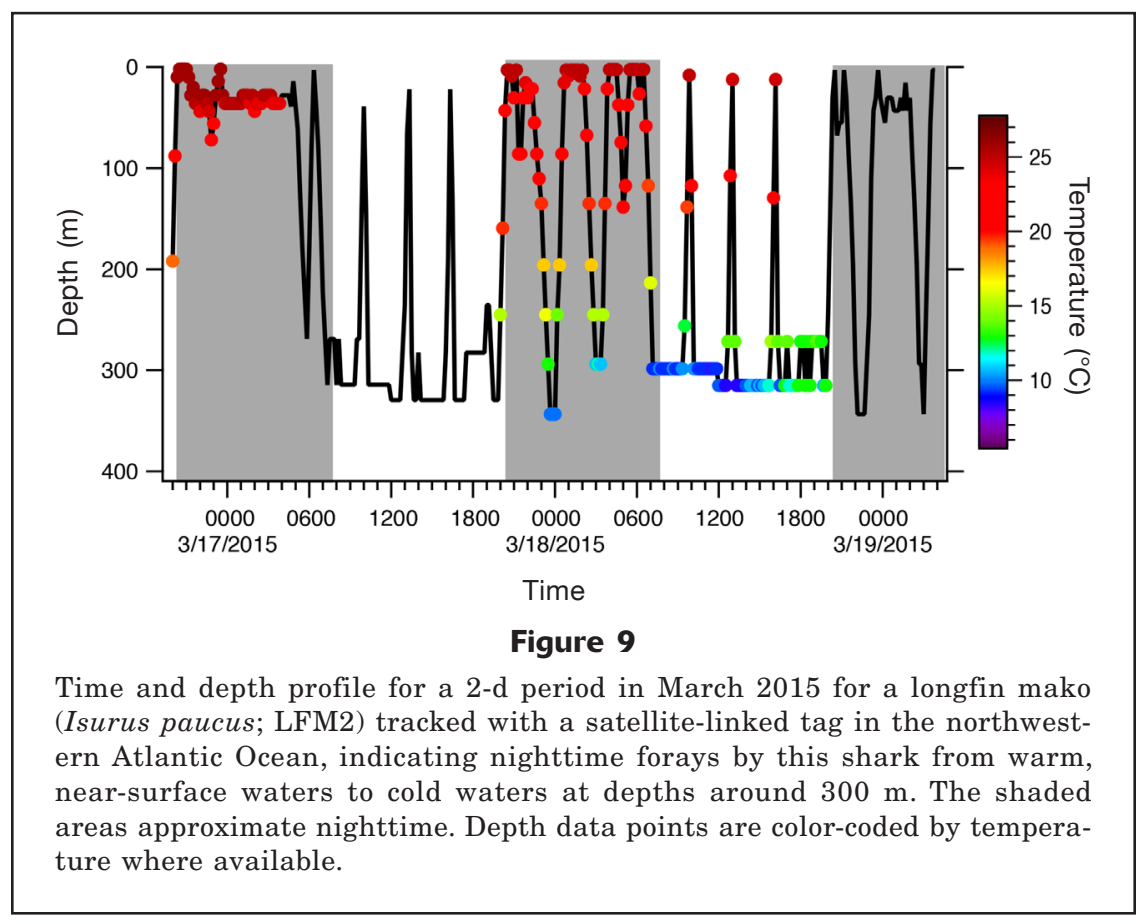

Lamnid shark species have the ability to conserve metabolic heat by means of vascular countercurrent heat exchangers (a complex called the retia mirabilia) and can maintain their tissues at temperatures significantly above ambient temperatures, likely as a means for broadening their habitat (Block and Carey, 1985; Goldman, 1997; Goldman et al., 2004). In a study of body temperature measurements and anatomical features related to heat production and conservation for lamnid species, the longfin mako was found to have a relatively small amount of red muscle and poorly developed retia mirabilia and consequently was rated as the least endothermic of the lamnid shark species (Carey et al., 1985). However, these authors suggest that the retia mirabilia of the longfin mako could increase its thermal inertia and prolong cooling time so that this shark species can maintain a body temperature higher than the ambient temperature in cold, deep waters after spending periods of time in warm surface waters. Our findings that daytime vertical activity and interforay duration both are related to temperature at depth (Figs. 7 and 8) are consistent with this hypothesis. Tracked shortfin makos have shown a similar pattern in the southeastern Pacific Ocean in that reduced thermal structure of the water column coincided with a decrease in the vertical activity of these fish (Abascal et al., 2011).

We hypothesize that LFM2 conducted regular forays during daytime from cold depths to surface waters to gain heat lost at depth. A similar daytime movement pattern from depth to surface waters has been described for the blue shark (Prionace glauca; Carey et al., 1990), and this movement pattern is a thermoregulatory strategy that is aided by the property of muscle to warm up more quickly than the time it takes to cool down (Carey and Gibson, 1987). In contrast to the blue shark, the endothermic longfin mako may be able to remain warmer than the ambient water temperature for longer periods of time at depth and then re-warm rapidly during relatively brief forays to the surface. This form of behavioral thermoregulation may enable longfin makos to remain active predators in cold water and to exploit agile, vertically migrating prey, such as pelagic squid species that would largely become unavailable (during the day) to competing ectothermic predators.

We also noted nighttime vertical oscillations of LFM2 from near surface waters to depths $>300 \mathrm{~m}$ (Fig. 9). The subsequent ascents brought this shark within $3 \mathrm{~m}$ of the surface, perhaps to regain heat after a period (20-40 min) at cold depths. For the shortfin mako, directed descents into deeper water, followed by rapid ascents (also known as bounce dives), have been associated primarily with daytime hours (Abascal et al., 2011) and have been correlated with successful feeding events at depth (Sepulveda et al., 2004). Although a DVM pattern has been reported for satellite-tracked jumbo squid, a highly variable amount of nighttime diving to depths in excess of $300 \mathrm{~m}$ has been observed for this species (Gilly et al., 2006). It is likely that the nighttime forays we observed with LFM2 are related to foraging and may be a response to variable nighttime movement patterns of its pelagic prey. The large size of the longfin mako (second largest of all lamnid species after the white shark, by length) may also be thermally advantageous by further minimizing conductive heat loss to surrounding sea water. Larger shortfin makos have been found to 
dive to greater maximum depths than those attained by smaller specimens (Sepulveda et al., 2004). As with all other lamnid shark species, the longfin mako has the capacity to maintain its visceral temperature substantially above ambient sea temperature through a suprahepatic rete (Carey et al., 1985; Bernal et al., 2012), which may be a mechanism for enhancing rates of digestion and food assimilation (Goldman 1997; Newton et al., 2015).

\section{Implications for conservation strategies}

Pelagic longline fisheries pose a principal threat to longfin makos (Reardon et al., 2006). Although bycatch data for this species are insufficient, there are published accounts of longfin makos having been captured in gear that targeted swordfish (Dodrill and Gilmore, 1979; Buencuerpo et al., 1998; Queiroz et al., 2006; Mucientes et al., 2013). In a report on the swordfish fishery along the east coast of Florida, Berkeley and Campos (1988) noted that more shark species than target species were captured and that the overall mortality rate was $66 \%$ for 13 species of hooked sharks. Furthermore, in a recent 1-year survey (conducted from October 2010 through November 2011) of the pelagic longline fishery along the northwestern coast of Cuba, the longfin mako was the second-most abundant shark species landed (by number), exceeded only by the shortfin mako, out of the 15 different shark species observed (Aguilar et al., 2014). A nearly 5-year (from October 2010 through April 2015) pilot monitoring program of the same fishery documented the longfin mako as the most abundant pelagic shark species landed (MINAL, 2015). Currently, there are no restrictions on catches of longfin makos in the waters of Cuba. In U.S. waters, the year-round or seasonal closing of areas to pelagic longline fisheries in the GOM and Atlantic Ocean appear to offer minimal protection for this species. Although based on only 2 tracks from 2 individuals, our data do not indicate that these sharks spent much time inside these closed areas, where they could have been protected from pelagic longlining.

The effect of this fishing pressure may be profound for the longfin mako, given its lower fecundity (2-8 pups per litter; Guitart Manday, 1975; Compagno, 2001) than that of the shortfin mako (4-25 pups per litter; Mollet et al., 2000; Compagno, 2001). The combination of this low productivity and high susceptibility of longfin makos to longline gear has led to this species being ranked as highly vulnerable in ecological risk assessments of shark species caught in pelagic longline fisheries (Cortés et al., 2010, 2015). With this vulnerability and generally lower abundance in comparison with its conspecific, for which it is often misidentified, the longfin mako is a shark species of special conservation concern in today's oceans.

The depths at which sharks distribute themselves profoundly affect their susceptibility to commercial fisheries (Speed et al., 2010). The diel vertical movement pattern of the longfin mako contributes to its vulnerability to pelagic longline fisheries, especially to fisheries that target swordfish. Results from a recent study, in which the satellite tracks of sharks were compared with fishing vessel movements in the North Atlantic Ocean, indicate how effectively pelagic longline fleets are exploiting key oceanic shark habitats, almost entirely overlapping fishing effort with preferred habitat of shark species for much of the year (Queiroz et al, 2016). With only 2 satellite tracks of longfin makos that covered periods of 3-5 months, the results of our study reveal connectivity in the range of this species among the territorial waters of 4 countries-the United States, Cuba, Mexico, and the Bahamas-and hence the vulnerability of this species to fishing fleets from multiple nations. More than $75 \%$ of species of pelagic sharks and rays have an elevated risk of extinction due to overfishing (Dulvy et al., 2008), and large pelagic shark species, such as the longfin mako, have an approximately $80 \%$ probability of being threatened (Dulvy et al., 2014). Effective management and assessment efforts, however, are often impeded by a lack of species-specific fishery and biological data. Although our study contributes new information to the limited knowledge of the longfin mako, continued efforts to improve data collection and the monitoring of pelagic shark catches, particularly in areas of concentrated abundance of longfin makos, such as those off the northern coast of Cuba, are warranted. The recent implementation of the first National Plan of Action for conservation and management of species of sharks and rays by Cuba (MINAL, 2015) is a positive step toward this goal.

\section{Acknowledgments}

We are indebted to the captains and crews of Florida Institute of Oceanography's RV Weatherbird II and of the MV Marinabella and FV Poco a Poco in Cuba. We sincerely thank our many Cuban colleagues, including L. Garcia Lopez, A. Alvarez Aleman, and C. Aguilar Betancourt of the Centro de Investigaciones Marinas, Universidad de la Habana, and F. Pina of the Centro de Investigaciones de Ecosistemas Costeros. Special gratitude is extended to Tandem Stills + Motion, Herzog \& Co., and Discovery Communications for documenting the work in Cuba. Permission to deploy satellite tags in Cuba was made possible through the dedicated efforts of D. Whittle of the Environmental Defense Fund and of Mundo Latino TV of Cuba. We thank J. Stewart for the R script used to generate likelihood surfaces and B. Galuardi for his helpful advice in constructing figures of sea-surface temperatures. We are grateful to P. Rogers and 2 anonymous reviewers for their input toward improving the manuscript. This work was funded by the Gulf of Mexico Research Initiative through the Florida Institute of Oceanography and by the Guy Harvey Ocean Foundation, Christopher Reynolds Foundation, Environmental Defense Fund, and Discovery Communications. 


\section{Literature cited}

Abascal, F. J., J. Mejuto, M. Quintans, and A. Ramos-Cartelle. 2010. Horizontal and vertical movements of swordfish in the Southeast Pacific. ICES J. Mar. Sci. 67:466-474. Article

Abascal, F. J., M. Quintans, A. Ramos-Cartelle, and J. Mejuto. 2011. Movements and environmental preferences of the shortfin mako, Isurus oxyrinchus, in the southeastern Pacific Ocean. Mar. Biol. 158:1175-1184. Article

Aguilar, C., G. González-Sansón, R. Hueter, E. Rojas, Y. Cabrera, A. Briones, R. Borroto, A. Hernández, and P. Baker. 2014. Captura de tiburones en la región noroccidental de Cuba. Lat. Am. J. Aquat. Res. 42:477-487.

Baum, J. K., R. A. Myers, D. G. Kehler, B. Worm, S. J. Harley, and P. A. Doherty.

2003. Collapse and conservation of shark populations in the northwest Atlantic. Science 299:389-392. Article

Berkeley, S. A., and W. L. Campos.

1988. Relative abundance and fishery potential of pelagic sharks along Florida's east coast. Mar. Fish. Rev. 50(1):9-16.

Bernal, D., J. K. Carlson, K. J. Goldman, and C. G. Lowe.

2012. Energetics, metabolism, and endothermy in sharks and rays. In Biology of sharks and their relatives, 2nd ed. (J. C. Carrier, J. A. Musick, and M. R. Heithaus, eds.), p. 211-237. CRC Press, Boca Raton, FL.

Block, B. A., and F. G. Carey.

1985. Warm brain and eye temperatures in sharks. J. Comput. Physiol. B 156:229-236. Article

Bruce, B. D., J. D. Stevens, and H. Malcom.

2006. Movements and swimming behaviour of white sharks (Carcharodon carcharias) in Australian waters. Mar. Biol. 150:161-172. Article

Buencuerpo, V., S. Rios, and J. Morón

1998. Pelagic sharks associated with the swordfish, Xiphias gladius, fishery in the Eastern North Atlantic Ocean and the Strait of Gibraltar. Fish. Bull. 96:667-685.

Bustamante, C., F. Concha, F. Balbontín, and J. Lamilla.

2009. Southernmost record of Isurus paucus Gitart Manday, 1966 (Elasmobranchii: Lamnidae) in the southeast Pacific Ocean. Rev. Biol. Mar. Oceanogr. 44:523-526. Article

Carey, F. G., and B. H. Robison.

1981. Daily patterns in the activities of swordfish, Xiphias gladius, observed by acoustic telemetry. Fish. Bull. 79:277-292.

Carey, F. G., and Q. H. Gibson.

1987. Blood flow in the muscle of free-swimming fish. Physiol. Zool. 60:138-148.

Carey, F.G., J. G. Casey, H. L. Pratt, D. Urquhart, and J. E. McCosker.

1985. Temperature, heat production and heat exchange in lamnid sharks. Mem. Calif. Acad. Sci. 9:92-108.

Carey, F. G., J. V. Scharold, and A. J. Kalmijn.

1990. Movements of blue sharks (Prionace glauca) in depth and course. Mar. Biol. 106:329-342. Article

Castelao, R., S. Glenn, O. Schofield, R. Chant, J. Wilkin, and J. Kohut.

2008. Seasonal evolution of hydrographic fields in the central Middle Atlantic Bight from glider observations. Geophys. Res. Lett. 35:L03617. Article

Castro, J. I.

2011. The sharks of North America, 613 p. Oxford Univ. Press, New York.
Clarke, S. C., J. E. Magnussen, D. L. Abercrombie, M. K. McAllister, and M. S. Shivji.

2006. Identification of shark species composition and proportion in the Hong Kong shark fin market based on molecular genetics and trade records. Conserv. Biol. 20:201-211. Article

Compagno, L. J. V.

2001. Sharks of the world: an annotated and illustrated catalogue of shark species known to date. Vol. 2: Bullhead, mackerel and carpet sharks (Heterodontiformes, Lamniformes and Orectolobiformes). FAO Species Catalogue for Fishery Purposes 1, vol. 2, 269 p. FAO, Rome.

Cortés, E., F. Arocha, L. Beerkircher, F. Carvalho, A. Domingo, M. Heupel, H. Holtzhausen, M. N. Santos, M. Ribera, and C. Simpfendorfer.

2010. Ecological risk assessment of pelagic sharks caught in Atlantic pelagic longline fisheries. Aquat. Living Resour. 23:25-34. Article

Cortés, E., A. Domingo, P. Miller, R. Forselledo, F. Mas, F. Arocha, S. Campana, R. Coelho, C. Da Silva, F. H. V. Hazin, et al.

2015. Expanded ecological risk assessment of pelagic sharks caught in Atlantic pelagic longline fisheries. Collect. Vol. Sci. Pap. ICCAT 71:2637-2688.

Dodrill, J. W, and R. G. Gilmore.

1979. First North American continental record of the longfin mako (Isurus paucus Guitart Manday). Fla. Sci. 42:52-58.

Dulvy, N. K., J. K. Baum, S. Clarke, L. J. V. Compagno, E. Cortés, A. Domingo, S. Fordham, S. Fowler, M. P. Francis, C. Gibson, et al.

2008. You can swim but you can't hide: the global status and conservation of oceanic pelagic sharks and rays. Aquat. Conserv: 18:459-482. Article

Dulvy, N. K., S. L. Fowler, J. A. Musick, R. D. Cavanagh, P. M. Kyne, L. R. Harrison, J. K. Carlson, L. N. K. Davidson, S. V. Fordham, M. P. Francis, et al.

2014. Extinction risk and conservation of the world's sharks and rays. eLife 2014;3:e00590. Article

Francis, M. P., J. C. Holdsworth, and B. A. Block.

2015. Life in the open ocean: seasonal migration and diel diving behaviour of Southern Hemisphere porbeagle sharks (Lamna nasus). Mar. Biol. 162:2305-2323. Article

Frédou, F. L., M. T. Tolotti, T. Frédou, F. Carvalho, H. Hazin, G. Burgess, R. Coelho, J. D. Waters, P. Travassos, and F. H. V. Hazin.

2015. Sharks caught by the Brazilian tuna longline fleet: an overview. Rev. Fish Biol. Fish. 25:365-377. Article

Galuardi, B, and M. Lutcavage.

2012. Dispersal routes and habitat utilization of juvenile Atlantic bluefin tuna, Thunnus thynnus, tracked with mini PSAT and archival tags. PLoS ONE 7(5):e37829. Article

Garrick, J. A. F.

1967. Revision of sharks of genus Isurus with description of a new species (Galeoidea, Lamnidae). Proc. U.S. Natl. Mus. 118:663-690.

Gilly, W. F., U. Markaida, C. H. Baxter, B. A. Block, A. Boustany, L. Zeidberg, K. Reisenbichler, B. Robison, G. Bazzino, and C. Salinas.

2006. Vertical and horizontal migrations by the jumbo squid Dosidicus gigas revealed by electronic tagging. Mar. Ecol. Prog. Ser. 324:1-17. Article 
Gilmore, R. G.

1983. Observations on the embryos of the longfin mako, Isurus paucus, and the bigeye thresher, Alopias superciliosus. Copeia 1983:375-382. Article

1993. Reproductive biology of lamnoid sharks. Environ. Biol. Fish. 38:95-114. Article

Goldman, K. J.

1997. Regulation of body temperature in the white shark, Carcharodon carcharias. J. Comput. Physiol. B 167:423-429. Article

Goldman, K. J., S. D. Anderson, R. J. Latour, and J. A. Musick. 2004. Homeothermy in adult salmon sharks, Lamna ditropis. Environ. Biol. Fish. 71:403-411. Article

Grace, M. A., W. B. Driggers III, J. Forrester, and N. Hopkins. 2007. Landing sling use increases data accuracy and sampling opportunities for large marine fishes captured during fishery-independent longline surveys. Fish. Res. 88:146-149. Article

Guitart Manday, D.

1966. Nuevo nombre para una especie de tiburón del génereo Isurus (Elasmobranchii: Isuridae) de aguas Cubanos. Poeyana (Inst. Biol.), A 15:1-9.

1975. Las pesquerías pelágico-oceánicas de corto radio de acciòn en la regiòn noroccidental de Cuba. Ser. Oceanol. Acad. Cienc. Cuba 31:1-26.

Hammerschlag, N., A. J. Gallagher, and D. M. Lazarre.

2011. A review of shark satellite tagging studies. J. Exp. Mar. Biol. Ecol. 398:1-8. Article

Hemida, F., and C. Capapé.

2008. On the occurrence of the longfin mako, Isurus paucus (Chondrichthyes: Isuridae) off the Algerian coast (southwestern Mediterranean). Acta Adriat. 49(2):185-189.

Hueter, R. E., C. A. Manire, J. P. Tyminski, J. M. Hoenig, and

D. A. Hepworth.

2006. Assessing mortality of released or discarded fish using a logistic model of relative survival derived from tagging data. Trans. Am. Fish. Soc. 135:500-508. Article

Killam, K., and G. Parsons.

1986. First record of the longfin mako, Isurus paucus, in the Gulf of Mexico. Fish. Bull. 84:748-749.

Kohler, N. E., J. G. Casey, and P. A. Turner.

1998. NMFS Cooperative Shark Tagging Program, 196293: an atlas of shark tag and recapture data. Mar. Fish. Rev. 60(2):1-87.

Kyne, P. M., J. K. Carlson, D. A. Ebert, S. V. Fordham, J. J. Bizzarro, R. T. Graham, D. W. Kulka, E. E. Tewes, L. R. Harrison, and N. K. Dulvy.

2012. The conservation status of North American, Central American, and Caribbean chondrichthyans, 148 p. IUCN Species Survival Commission Shark Specialist Group, Vancouver, Canada.

Loefer, J. K., G. R. Sedberry, and J. C. McGovern.

2005. Vertical movements of a shortfin mako in the western north Atlantic as determined by pop-up satellite tagging. Southeast. Nat. 4:237-246.

Logan, J. M., R. Toppin, S. Smith, B. Galuardi, J. Porter, and M. Lutcavage.

2013. Contribution of cephalopod prey to the diet of large pelagic fish predators in the central North Atlantic Ocean. Deep Sea Res. (Part II: Top. Stud. Oceanogr.) 95:74-82. Article

Maia, A., N. Queiroz, J. P. Correia, and H. Cabral.

2006. Food habits of the shortfin mako, Isurus oxyrinchus, off the southwest coast of Portugal. Environ. Biol. Fish. 77:157-167. Article
MINAL (Ministry for the Food Industry).

2015. National plan of action for the conservation and management of Chondrichthyes in the Republic of Cuba, 48 p. Ministry for the Food Industry, Havana, Cuba

Mollet, H. F., G. Cliff, H. L. Pratt Jr., and J. D. Stevens.

2000. Reproductive biology of the female shortfin mako, Isurus oxyrinchus Rafinesque, 1810, with comments on the embryonic development of lamnoids. Fish. Bull. 98:299-318.

Mucientes, G., R. Bañón, and N. Queiroz.

2013. Updated distribution range of longfin mako Isurus paucus (Lamniformes: Lamnidae) in the North Atlantic. J. Appl. Ichthyol. 29:1163-1165. Article

Musyl, M. K., R. W. Brill, C. H. Boggs, D. S. Curran, T. K. Kazama, and M. P. Seki.

2003. Vertical movements of bigeye tuna (Thunnus obesus) associated with islands, buoys, and seamounts near the main Hawaiian Islands from archival tagging data Fish. Oceanogr. 12:152-169. Article

Nasby-Lucas, N., H. Dewar, C. H. Lam, K. J. Goldman, and M. L. Domeier.

2009. White shark offshore habitat: a behavioral and environmental characterization of the eastern Pacific shared offshore foraging area. PLoS ONE 4(12):e8163. Article

Newton, K. C., J. Wraith, and K. A. Dickson.

2015. Digestive enzyme activities are higher in the shortfin mako shark, Isurus oxyrinchus, than in ectothermic sharks as a result of visceral endothermy. Fish Physiol. Biochem. 41:887-898. Article

Pade, N. G., N. Queiroz, N. E. Humphries, M. J. Witt, C. S. Jones, L. R. Noble, and D. W. Sims.

2009. First results from satellite-linked archival tagging of porbeagle sharks, Lamna nasus: area fidelity, widerscale movements and plasticity in diel depth changes. J. Exp. Mar. Biol. Ecol. 370:64-74. Article

Queiroz, N., S. Araújo, P. A. Ribeiro, P. Tarroso, R. Xavier, and A. M. Santos.

2006. A first record of longfin mako, Isurus paucus, in the mid-North Atlantic. Mar. Biodivers. Rec. 1:e34. Article

Queiroz, N., N. E. Humphries, G. Mucientes, N. Hammerschlag, F. P. Lima, K. L. Scales, P. I. Miller, L. L. Sousa, R. Seabra, and D. W. Sims.

2016. Ocean-wide tracking of pelagic sharks reveals extent of overlap with longline fishing hotspots. Proc. Natl. Acad. Sci. U.S.A. 113:1582-1587. Article

$\mathrm{R}$ Core Team.

2015. R: a language and environment for statistical computing. R Foundation for Statistical Computing, Vienna, Austria. [Available from website, accessed January 2016.]

Reardon, M. B., L. Gerber, and R. D. Cavanagh.

2006. Isurus paucus. The IUCN Red List of Threatened Species 2006: e.T60225A12328101. Article

Rogers, P. J., C. Huveneers, B. Page, S. D. Goldsworthy, M. Coyne, A. D. Lowther, J. G. Mitchell, and L. Seuront.

2015. Living on the continental shelf edge: habitat use of juvenile shortfin makos Isurus oxyrinchus in the Great Australian Bight, southern Australia. Fish. Oceanogr. 24:205-218. Article

Roper, C. F. E., and R. E. Young.

1975. Vertical distribution of pelagic cephalopods. Smithson. Contrib. Zool. 209, 51 p. Article 
Saunders, R. A., F. Royer, and M. W. Clarke.

2011. Winter migration and diving behaviour of porbeagle shark, Lamna nasus, in the Northeast Atlantic. ICES J. Mar. Sci. 68:166-174. Article

Sebastian, H., P. A. Haye, and M. S. Shivji.

2008. Characterization of the pelagic shark-fin trade in north-central Chile by genetic identification and trader surveys. J. Fish Biol. 73:2293-2304. Article

Sembiring, A., N. P. D. Pertiwi, A. Mahardini, R. Wulandari, E. M. Kurniasih, A. W. Kuncoro, N. K. D. Cahyani, A. W. Anggoro, M. Ulfa, H. Madduppa, et al.

2015. DNA barcoding reveals targeted fisheries for endangered sharks in Indonesia. Fish. Res. 164:130-134. Article

Sepulveda, C. A., S. Kohin, C. Chan, R. Vetter, and J. B. Graham.

2004. Movement patterns, depth preferences, and stomach temperatures of free-swimming juvenile mako sharks, Isurus oxyrinchus, in the Southern California Bight. Mar. Biol. 145:191-199. Article

Sepulveda, C. A., A. Knight, N. Nasby-Lucas, and M. L. Domeier.

2010. Fine-scale movements of the swordfish Xiphias gladius in the Southern California Bight. Fish. Oceanogr. 19:279-289. Article

Speed, C. W., I. C. Field, M. G. Meekan, and C. J. A. Bradshaw.

2010. Complexities of coastal shark movements and their implications for management. Mar. Ecol. Prog. Ser. 408:275-293. Article
Stevens, J. D., R. W. Bradford, and G. J. West.

2010. Satellite tagging of blue sharks (Prionace glauca) and other pelagic sharks off eastern Australia: depth behaviour, temperature experience and movements. Mar. Biol. 157:575-591. Article

Stillwell, C. E., and N. E. Kohler.

1982. Food, feeding habits, and estimates of daily ration of the shortfin mako (Isurus oxyrinchus) in the northwest Atlantic. Can. J. Fish. Aquat. Sci. 39:407-414. Article

Wakida-Kusunoki, A. T., and D. de Anda-Fuente.

2012. Presence of longfin mako shark Isurus paucus (Chondrichthyes: Lamnidae) in the south-eastern Gulf of Mexico, Tabasco, Mexico. Mar. Biodivers. Rec. 5:e92. Article

Weng, K. C., P. C. Castilho, J. M. Morrissette, A. M. LandeiraFernandez, D. B. Holts, R. J. Schallert, K. J. Goldman, and B. A. Block.

2005. Satellite tagging and cardiac physiology reveal niche expansion in salmon sharks. Science 310:104-106 Article

Weng, K. C., A. M. Boustany, P. Pyle, S. D. Anderson, A. Brown, and B. A. Block.

2007. Migration and habitat of white sharks (Carcharodon carcharias) in the eastern Pacific Ocean. Mar. Biol. 152:877-894. Article

Weng, K. C., D. G. Foley, J. E. Ganong, C. Perle, G. L. Shillinger, and B. A. Block.

2008. Migration of an upper trophic level predator, the salmon shark Lamna ditropis, between distant ecoregions. Mar. Ecol. Prog. Ser. 372:253-264. Article 